Egyptian Journal of Aquatic Biology \& Fisheries

Zoology Department, Faculty of Science,

Ain Shams University, Cairo, Egypt.

ISSN $1110-6131$

Vol. 22(4): 167- 179 (2018)

ejabf.journals.ekb.eg

\title{
Growth response, nutrient utilization, biochemical and hematological parameters of Juvenile African catfish (clarias gariepinus) fed diet supplemented with gongronema latifolia (benth) extract.
}

\author{
Aderolu, Ademola zaid \\ Department of Marine sciences, University of Lagos, Nigeria \\ dezaid@yahoo.com
}

\section{ARTICLE INFO \\ Article History: \\ Received: Aug. 11, 2018 \\ Accepted: Sept. 10, 2018 \\ Available online: Sept. 20, 2018}

Keywords:

Clarias gariepinus

fish diet

growth performance

G. latifolia

oxidative stress

liver toxicity

\begin{abstract}
This study investigated the effect of varying levels of Gongronema latifolia on growth, nutrient utilization, biochemical and hematological parameters of Clarias gariepinus juveniles. One hundred and five (105) juveniles were equally distributed in fifteen plastics tanks and each triplicated. Three inclusion levels of the plant extract $(150 \mathrm{mg} / \mathrm{kg}$, $300 \mathrm{mg} / \mathrm{kg}$ and $500 \mathrm{mg} / \mathrm{kg}$ ) were prepared, while the antibiotics served as negative control and the diet without any inclusion served as the positive control. The fish meal was supplemented with Gongronema latifolia (benth) extract and the control diets were fed to satisfaction, while the tank water was changed every other day. The weight gained and feed intakes of the fish were determined at the end of every week and the growth parameters were evaluated. Growth parameters showed that the highest value was recorded in treatment $4(300 \mathrm{mg}) 226.07 \pm 9.96$ for the final weight gained, while the lowest was observed in treatment $5(500 \mathrm{mg}$ ) was 165.47 \pm 31.55 . Supplementation of fish feed on Gongronema latifolia did not cause any adverse effects on biomarkers of liver toxicity and oxidative stress. Monocytes and lymphocytes concentration were significantly reduced with no alteration in red blood cell count and hemoglobin concentration. This study showed that the supplementation of Clarias gariepinus juvenile diet with $G$. latifolia extract promoted growth and weight gain in the fish stock with no toxic effect on the liver and oxidative stress.
\end{abstract}

\section{INTRODUCTION}

Medicinal plants was defined by Sofowora et al. (2013) as any plant which, in one or more of its organs, contains substances that can be used for therapeutic purposes or which are precursors for the synthesis of useful drugs.

Natural products, such as plant extract, either as pure compounds or as standardized extracts, provide unlimited opportunities for new drug discoveries because of the unmatched chemical diversity they can provide (Cos et al., 2006). Several studies indicated that medicinal plants contain compounds like peptides, unsaturated long chain fatty acids, aldehydes, alkaloids, essential oils, phenols and water or ethanol soluble compounds. These compounds are significant in therapeutic application against human and animal pathogens, including bacteria, fungi and viruses (Pavrez et al., 2005). 
According to the World Health Organization (WHO), more than $80 \%$ of the world's population relies on traditional medicine for their primary health care needs. This has captured the interest of many researchers to explore local medicinal plants for valuable medicinal traits. In recent years, numerous drug resistances in human pathogenic microorganisms have developed due to their indiscriminate use and their leakages into the environment inform of pharmaceutical effluents and pesticides (Igbinosa and Odjadjare 2015).

The impact of antibiotic-resistant bacteria on human health has become a major international concern in recent years and attention has focused on food-producing animals as one of several potential sources of antibiotic-resistant bacteria in humans (Wegener 2012). These resistant bacteria may spread from animals to humans via the food chain and they may also transfer their antibiotic-resistance genes into human pathogenic bacteria, leading to failure of antibiotic treatment for some lifethreatening conditions (Von wintersdorff et al., 2016). At the same time, other side effects, such as the residual impact on the environment, are also risk factors when commercial antibiotics are used for treatment of disease in Fish.

Gongronema latifolium (Benth) is of West African Origin (Nelson, 1965). It belongs to the family Asclepiadaceae. It is an edible nutritional plant with medicinal potential found mostly in the rain forest zones in Nigeria and other tropical African countries (Chattopadhyah 1999). G. latifolium is known by the Ikale tribes of Ondo State of Nigeria as Iteji (Morebise et al 2006). The Ibos call the plant Utazi, the Efik/ Ibibio call it Utasi while the Yorubas call it Arokeke (Edim et al., 2012). Bello et al 2014, Akpan and Ekpo (2015) listed it phytochemical and scientific composition, while Eleyinini (2007) listed its antibacterial activities and Emeka and Obidoa (2009) finally establishes its antioxidant potentials.

With increased incidence of resistance to antibiotics, natural products from plants could be an interesting alternative (Mbwambo et al., 2007). Natural plants products present a viable alternative to antibiotics and other banned drugs being safer for the reared organism and humans, as well as the environment. The use of medicinal plants could definitely complement advances to medicine in many parts of the world (American Society for Testing and Materials, 2001) because of the presence of wide range of bio-active phyto-chemicals and secondary metabolites.

\section{MATERIALS AND METHODS}

\section{The experimental site}

The experiment was carried out at the Nutrition Unit of the Department of Marine Sciences, Faculty of Science, University of Lagos, Akoka.

\section{Collection and identification of sample}

Fresh samples of Gongronema latifolia was sourced at a local market in Mushin, Lagos state, Nigeria. The plant material was taken to the Department of Botany Herbarium, University of Lagos for identification. The samples were thoroughly rinsed with clean water and evenly spread on a mosquito net-size mesh to air dry under shade. After complete dryness, the leaves were powdered using an Electric blender (Mbagwu and Adeniyi, 1988). Extracts with best antioxidant and antibacterial activities, among various solvent extractions from previous studies (Aderolu et al. 2017) was used in the feeding experiment.

\section{Procurement of experimental fish}

A total number of one hundred and five $(82.0 \pm 2.0 \mathrm{~g}$ initial mean weight $)$ of Clarias gariepinus juvenile were purchased from a reputable farm in Ikotun Egbe, 
Lagos. The fish were transferred to the unit and acclimatized for two (2) weeks being fed with commercial diet before the introduction of experimental diet. They were kept under standard condition; temperature $(27.5$ - 29.5 $\mathrm{c}$ ), dissolved oxygen (4.5 $4.8 \mathrm{mg} / \mathrm{l})$, and $\mathrm{pH}(7.3$ - 8.0) as described by Aderolu and Akpabio (2009).

\section{Experimental Design}

The fish were weighed and distributed into the 15 plastic bowls representing five treatments each replicated thrice; at the rate of (7) seven fish per bowl (52 x 33.5 $\mathrm{x} 21 \mathrm{~cm}$ ). The tanks were separated into five (5) experimental groups of $0 \mathrm{mg}$ (control), Antibiotics (oxythetramycine at $200 \mathrm{mg} / \mathrm{kg}$ ) (negative control) $150 \mathrm{mg} / \mathrm{kg}$, $300 \mathrm{mg} / \mathrm{kg}, 500 \mathrm{mg} / \mathrm{kg}$ concentration of Gongronema latifolia extracts. All the experimental fish, were fed twice daily to satiation between the hours of 08: $00-$ 09.00 and 16: $00-17.00$ for eight weeks. Fish were batched weighed weekly with a digital scale (Camry EK5055 Max 5kg/11 lb. d = 1g/0.05 oz.) and mortality was monitored daily (56 days).

\section{Purchase and Processing of Feed Ingredients}

All other feed ingredients were sourced from Abattoir, Agege, Lagos, Nigeria. The ingredients for each diet were mixed thoroughly in a bowl with the extract being added to it and pelletized with a locally-fabricated pelletizing machine. The moist pellets were sun dried for eight hours, packaged in air tight plastic containers, tagged and refrigerated until needed.

\section{Experimental diet preparations}

The greasy plant extract was weighed and dissolved in sterile distilled water to prepare appropriate dilution to get required concentrations. Five experimental diets were prepared, the supplement (Gongronema latifolia) was included at $150 \mathrm{mg}$, $350 \mathrm{mg}$, and $500 \mathrm{mg} / \mathrm{kg}$ respectively to form three isonitrogeneous experimental diets (35\% Crude Protein). 0\% inclusion level served as control diet and antibiotics as negative control. Fish feed was formulated to meet the nutrient requirement of the fish (Aderolu and Akpabio 2009). They were kept under refrigerated condition until they are needed for the experiment.

Table 1: Nutrient composition of experimental diet used in this study

\begin{tabular}{|c|c|c|c|c|c|}
\hline \multirow[t]{2}{*}{ Ingredients (\%) } & \multirow{2}{*}{$\begin{array}{l}\text { Treatment-1 } \\
\text { (+tive Control1) }\end{array}$} & \multirow{2}{*}{$\begin{array}{l}\text { Treatment-2 } \\
\text { (- tive Control2) }\end{array}$} & \multicolumn{3}{|c|}{ Concentration of plant extract in the diet } \\
\hline & & & $\begin{array}{c}\text { Treatment-3 } \\
(150 \mathrm{mg})\end{array}$ & $\begin{array}{c}\text { Treatment-4 } \\
(300 \mathrm{mg})\end{array}$ & $\begin{array}{l}\text { Treatment-5 } \\
\text { (500mg) }\end{array}$ \\
\hline Fish meal (72\%) & 17.15 & 17.15 & 17.15 & 17.15 & 17.15 \\
\hline Soybean meal & 19.10 & 19.10 & 19.10 & 19.10 & 19.10 \\
\hline Groundnut cake & 19.10 & 19.10 & 19.10 & 19.10 & 19.10 \\
\hline Maize & 20.40 & 20.40 & 20.40 & 20.40 & 20.40 \\
\hline Noodle waste & 20.40 & 20.40 & 20.40 & 20.40 & 20.40 \\
\hline Plant oil & 1.00 & 1.00 & 1.00 & 1.00 & 1.00 \\
\hline Di calcium phosphate & 0.40 & 0.40 & 0.40 & 0.40 & 0.40 \\
\hline Lysine & 0.20 & 0.20 & 0.20 & 0.20 & 0.20 \\
\hline Methionine & 0.20 & 0.20 & 0.20 & 0.20 & 0.20 \\
\hline Mineral-Vitamin premix & 1.75 & 1.75 & 1.75 & 1.75 & 1.75 \\
\hline Salt & 0.30 & 0.30 & 0.30 & 0.30 & 0.30 \\
\hline Plant extract(mg/kg) & - & - & 150 & 300 & 500 \\
\hline Antibiotics $(\mathrm{mg} / \mathrm{kg})$ tetracycline & - & 200 & - & - & - \\
\hline Total $(\mathrm{kg})$ & 100 & 100 & 100 & 100 & 100 \\
\hline Calculated CP $(\%)$ & 35 & 35 & 35 & 35 & 35 \\
\hline Calculated Energy (Kcal) & 3127 & 3127 & 3127 & 3127 & 3127 \\
\hline
\end{tabular}

\section{Growth and nutrient utilization parameters}

The following parameters were obtained from the record of feed intake and weight gain record; 
Feed Conversion Ratio (FCR)

FCR Error! Reference source not found. . Feed intake Weight gain

Final Weight Gain (FWG)

FWG $=$ Final weight - Initial weight

Mean Weight Gain (MWG)

$\mathrm{MWG}=\underline{\text { Average Weight Gain }}$

No of days of experiment

Specific growth Rate (SGR)

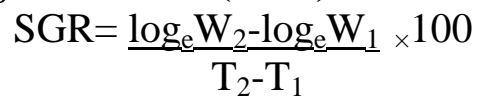

(Where, e $=$ Natural logarithm, $\mathrm{T}_{2}-\mathrm{T}_{1}=$ experimental period, $\mathrm{W}_{1}=$ initial weight, $\mathrm{W}_{2}$ = final weight)

Relative Growth Rate (RGR)

RGR $=\frac{\text { weight gain }}{\text { Initial body weight }}$
Average Feed Intake (AFI)
AFI $=\frac{\text { Total Feed intake }}{\text { No of days of experiment }}$
Protein Intake (PI)
PI $=\frac{\text { Total feed intake }}{\text { Protein content of feed }}$
Protein Efficiency Ratio (PER)
PER $=\frac{\text { Mean weight gained }}{\text { Protein intake }}$
Hematological analysis

The following parameters were used to assess the effects of dietary treatments on the haematological profile of Clarias gariepinus at the end of the feeding trials. Blood samples for hematological analysis were collected from the fish with a plastic syringe ( $2 \mathrm{ml}$ capacity) at the caudal peduncle of both the exposed and control fish. Three fish per treatment, the blood was immediately withdrawn into an EDTA bottle and plain bottles for hematological and biochemical analysis. The samples were then analyzed in the Department of Medical Laboratory Science of University of Lagos (LUTH). For hematological analysis, the semi-automated hematology analyzer (Mindray) from China was used. The following hematological parameters were evaluated:

Erythrocyte Count (Red Blood Cell)

Fish blood was diluted in an improved Neubauer pipette with citrate buffer fluid at 1: 200. The diluted blood was introduced into a Neubauer counter/ counting chamber and red blood cells counted under the microscope (Shah and Altindag, 2004).

\section{Pack cell volume}

Hematocrit was determined by filling the heparinized capillary tubes with blod samples and then centrifuged with a hematocrit centrifuge. The PCV was determined with hematocrit reader and expressed in percent (Shah and Altindag, 2004).

\section{Haemoglobin concentration}

Hemoglobin concentration was determined using calorimeter method. Briefly, the hemoglobin is converted to oxyhemoglobin by adding about $40 \mathrm{~cm} 3$ of the blood sample to $4 \mathrm{ml}$ of $0.04 \%$ ammonium solution in a test tube. The optical density of the oxyhemoglobin formed was red with a calorimeter. The optical density was thereafter 
converted to hemoglobin concentration on the standard calibration curve (Roberts, 1978).

\section{Leucocytes count (White Blood Cell)}

Fish blood was diluted in an improved Neubauer pipette with citrate buffer fluid at 1: 20. The resulting mixture was introduced into a Neubauer counter/ counting chamber and white blood cells counted under the microscope at a magnification of x40 (Shah and Altindag, 2004).. Differential white blood cell count was determined by preparing a thin blood film by spreading a drop of blood evenly across a clean grease free slide, using smooth edged spreader. The blood film was fixed with absolute methanol for 3 to 5 minutes and allowed to dry. The smear was stained with giemsa stain and 100 white blood cells were differentiated using the oil immersion objectives of the microscope. The percentage of each white cells type was extrapolated (Blaxhall and Diasley, 1973).

\section{Biochemical analysis}

Samples of blood in the plain bottles were spun at 3,000 rpm to collect the serum that was used in biochemical analysis which includes protein, albumin, cholesterol, triglyceride, HDL, LDL, AST, ALT and ALP.

Liver sample $(0.5 \mathrm{~g})$ was carefully collected over ice and homogenized in $5 \mathrm{ml}$ of normal saline solution. The homogenate was centrifuged at $3000 \mathrm{rpm}$ for 5 minutes at $-4{ }^{\circ} \mathrm{C}$. The supernatant was separated into a sterile sample bottle and used for the following biochemical analysis; Alanine aminotransferase (ALT), aspartate aminotransferase (AST) Reitman and Frankel (1957), alkaline phosphatase (ALP) (Bessey et al.,1946), Reduced Glutathione (GSH), Superoxide Dismutase (SOD), Catalase, Malondialdehyde (MDA). Total serum protein, serum albumin and serum globulin was also determined from the blood samples.

\section{Total Protein}

This was determined using Buiret method (Gonall et al., 1949) and Bovine Serum Albumin (BSA) as standard. The Principle Polypeptides and proteins with two or more peptides bonds give a characteristic purple/violet color when treated with diluted copper sulfate at alkaline $\mathrm{pH}$ values. In other words, Alkaline copper sulphate reacts with compounds containing two or more peptide bonds to give a violet or purple coloured complex. The intensity of colour obtained is a measure of the number of peptide bonds present in the protein. The mixture of the reagent and serum sample was incubated for 30 minutes at $20-25^{\circ} \mathrm{C}$ and the absorbance of the sample and that of the standard was measured against the blank at a wavelength of $540 \mathrm{~nm}$.

The total protein concentration was calculated as;

$$
\text { Total protein }(\mathrm{g} / \mathrm{dl})=\frac{\text { Absorbance of Sample }}{\text { Absorbance of standard }} \quad \mathrm{x} \text { Standard Concentration }
$$

\section{Serum Albumin}

The Bromo-Cresol Green (BCG) method as described by Donmas et al., (1971) was employed. The absorbance of the sample and the standard were taken against the reagent blank, at a wavelength of $620 \mathrm{~nm}$.

Albumin $(\mathrm{g} / \mathrm{dI})$ concentration $=\underline{\text { Absorbance of sample }} \times \quad$ Concentration of Standard

\section{Serum Globulin (g/dl)}

Absorbance of standard

Serum globulin was calculated as follows;

Serum globulin $(\mathrm{g} / \mathrm{dl})=$ Total serum Protein $(\mathrm{g} / \mathrm{dl})-$ Serum albumin $(\mathrm{g} / \mathrm{dl})$ 


\section{Liver Antioxidant Enzymatic Activities}

The following antioxidant enzymes activities were determined using spectrophotometer as follows:

\section{Determination of Superoxide Dismutase (SOD) activity}

Superoxide Dismutase activity was determined by its ability to inhibit the autooxidation of epinephrine determined by the increase in absorbance at 480nm as described by Sun and Zigma (1978). The reaction mixture $(3 \mathrm{ml})$ contained $2.95 \mathrm{ml}$ $0.05 \mathrm{M}$ sodium carbonate buffer $\mathrm{pH} 10.2,0.02 \mathrm{ml}$ of liver homogenate and $0.03 \mathrm{ml}$ of epinephrine in $0.005 \mathrm{~N} \mathrm{HCL}$ was used to initiate the reaction. The reference cuvette contained $2.95 \mathrm{ml}$ buffer, $0.03 \mathrm{ml}$ of substrate (epinephrine) and $0.02 \mathrm{ml}$ of water. Enzyme activity was calculated by measuring the change in absorbance at $480 \mathrm{~nm}$ for 5 min.

\section{Determination of Catalase Activity}

This was determined adopting the methods of Aksenes and Njaa (1981). Hydrogen peroxide was prepared with phosphate buffer; $0.2 \mathrm{ml}$ of sample was added to $1.8 \mathrm{ml}$ of $30 \mathrm{mM}$ of hydrogen peroxide $\left(\mathrm{H}_{2} \mathrm{O}_{2}\right)$ substrate in a $2 \mathrm{ml}$ curvette. The phosphate buffers were used as a blank. The absorbance for the test sample, blank and standard was read against a blank at $240 \mathrm{~nm}$ at 30s interval for $1 \mathrm{~min}$. The enzyme activity was calculated using the molar extinction coefficient of $40.00 \mathrm{M}^{-1}$ $\mathrm{cm}^{-1}$ expressed as unit/mg protein

\section{Reduced Glutathione Determination (GSH)}

The reduced glutathione (GSH) content of serum non-protein sulphydryls was estimated according to the method described by Sedlak and Lindsay (1968). To the liver homogenate $10 \%$ TCA was added, centrifuged. $1.0 \mathrm{ml}$ of supernatant was treated with $0.5 \mathrm{ml}$ of Elman's reagent (19.8mg of 5,5-dithiobisnitro benzoic acid (DTNB) in $100 \mathrm{ml}$ of $0.1 \%$ sodium nitrate) and $3.0 \mathrm{ml}$ of phosphate buffer $(0.2 \mathrm{M}, \mathrm{pH} 8.0)$. The absorbance was read at $412 \mathrm{~nm}$. The enzyme activity was calculated using the molar extinction coefficient of $\sum=1.34 \times 10^{4} \mathrm{M}^{-1} \mathrm{~cm}^{-1}$

\section{Lipid Peroxidation (MDA)}

Malondialdehyde (MDA) an index of lipid peroxidation was determined using the method of Buege and Aust (1978). $1.0 \mathrm{ml}$ of the supernatant was added to $2 \mathrm{ml}$ of (1:1:1 ratio) TCA-TBA- $\mathrm{HCl}$ reagent (thiobarbituric acid $0.37 \%, 0.24 \mathrm{~N} \mathrm{HCl}$ and $15 \%$ TCA) tricarboxylic acid- thiobarbituric acid-hydrochloric acid reagent boiled at $100^{\circ} \mathrm{C}$ for $15 \mathrm{~min}$, and allowed to cool. Flocculent materials were removed by centrifuging at $3000 \mathrm{rpm}$ for $10 \mathrm{~min}$. The supernatant was removed and the absorbance read at $532 \mathrm{~nm}$ against a blank. MDA was calculated using the molar extinction coefficient for MDATBA- complex of $1.56 \times 10^{5} \mathrm{M}^{-1} \mathrm{CM}^{-1}$.

\section{Statistical analysis and result presentation}

A one way analysis of variance (ANOVA) was employed on the data using SPSS 16.0 statistical package to describe growth and nutrient utilization performances along side biochemical and haematological parameters and to test for

\section{RESULTS}

Growth and nutrient utilization in juvenile Clarias gariepinus fed diet supplemented with graded levels of Gongronema latifolia leaf extract

Growth and nutrient parameters are presented in Table 2. Mean body weight gain and specific growth rate were significantly different at the 500mg (T-5) inclusion level among fish fed graded levels of the plant extract only. Feed intake and 
protein intake were equally only significantly different in the 500mg diet (T-5) relative to other diets.

Table 2: Growth performance, nutrient utilization C. gariepinus juvenile fed different graded levels of Gongronema latifolium.

\begin{tabular}{|c|c|c|c|c|c|}
\hline Parameters & $\begin{array}{c}\text { Treatment-1 } \\
(+ \text { tive Control) }\end{array}$ & $\begin{array}{c}\text { Treatment-2 } \\
\text { (- tive control) } \\
\text { (antibiotics) }\end{array}$ & $\begin{array}{c}\text { Treatment-3 } \\
(150 \mathrm{mg})\end{array}$ & $\begin{array}{l}\text { Treatment-4 } \\
\text { (300mg) }\end{array}$ & $\begin{array}{c}\text { Treatment-5 } \\
(500 \mathrm{mg})\end{array}$ \\
\hline I NW (g) & $82.87 \pm 0.27$ & $82.91 \pm 0.08$ & $83.05 \pm 0.22$ & $83.15 \pm 0.25$ & $83.00 \pm 0.14$ \\
\hline FWG (g) & $191.47 \pm 3.19^{\mathrm{ab}}$ & $214.93 \pm 18.90^{b}$ & $222.57 \pm 13.29^{b}$ & $226.07 \pm 9.96^{b}$ & $165.47 \pm 31.55^{\mathrm{a}}$ \\
\hline MWG (g) & $108.60 \pm 3.00^{\mathrm{ab}}$ & $132.03 \pm 18.8 .^{b}$ & $139.52 \pm 13.30^{b}$ & $143.07 \pm 9.82^{b}$ & $82.32 \pm 31.72^{\mathrm{a}}$ \\
\hline $\mathrm{AFI}(\mathrm{g})$ & $142.13 \pm 8.82^{b}$ & $154.63 \pm 7.19^{b}$ & $154.63 \pm 12.45^{b}$ & $163.53 \pm 9.32^{b}$ & $117.20 \pm 10.50^{\mathrm{a}}$ \\
\hline PI & $49.75 \pm 3.09^{b}$ & $54.12 \pm 2.52^{b}$ & $54.12 \pm 4.36^{\mathrm{b}}$ & $57.24 \pm 3.26^{\mathrm{b}}$ & $41.02 \pm 3.68^{\mathrm{a}}$ \\
\hline FCR & $1.62 \pm 0.09$ & $1.27 \pm 0.31$ & $1.44 \pm 0.88$ & $1.36 \pm 0.17$ & $2.04 \pm 0.09$ \\
\hline PER & $1.77 \pm 0.91$ & $2.34 \pm 0.59$ & $1.99 \pm 0.12$ & $1.67 \pm 0.40$ & $2.12 \pm 0.26$ \\
\hline SGR (\%/day) & $1.50 \pm 0.26^{\mathrm{ab}}$ & $1.70 \pm 0.16^{\mathrm{b}}$ & $1.76 \pm 0.11^{b}$ & $1.79 \pm 0.75^{b}$ & $1.21 \pm 0.36^{\mathrm{a}}$ \\
\hline
\end{tabular}

Means with different superscripts along the row are significantly different $(\mathrm{P}<0.05)$ INW- initial weight, FBW- final body weight, FWG- final weight gain, MWG- mean weight gain, AFI- taverage feed intake, SGR- specific growth rate, FCR- feed conversion ratio, PER-protein efficiency ratio, PIprotein intake.

\section{Broken and non-linear polynomial line showing optimal inclusion level of Gongronema latifolia in the diets for juvenile Clarias gariepinus.}

The result in Figure 1 showed the highest MWG of the fish fed experimental diets corresponds to $(143.07 \pm 9.82 \mathrm{~g})$. The further increment in the concentration of the plant extract (Gongronema latifolia) from the graph showed a reduction in MWG. The graph showed the best recommended dosage of $220 \mathrm{mg} / \mathrm{kg}$.

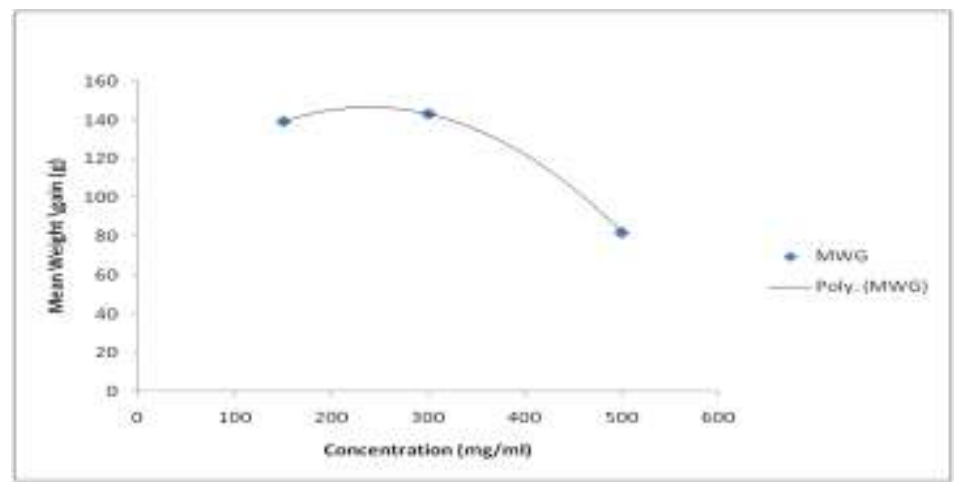

Fig. 1: Broken and non-linear polynomial line showing optimal inclusion level of Gongronema latifolia in the diets for juvenile Clarias gariepinus

\section{Hematological parameters of Clarias gariepinus fed Gongronema latifolium supplemented diet along with negative and positive controls.}

The haematological parameters measured in the blood samples from Clarias gariepinus fed different graded levels of Gongronema latifolia extract supplemented diets along with the negative and positive controls are presented in Table 3. There was a significant decrease in white blood cell count in all groups fed extract supplemented diet compared to the positive control. The decreases in white blood cell count recorded in T-4 and T-5 groups were also significantly reduced compared with the negative control results. The differential white blood cell count showed a significant decrease in monocyte count in all extract treated groups compared with control. Similarly, there was significant decrease in the lymphocyte count in the 
negative control treated with antibiotics and all the extract treated groups. The red blood cell count was not different in all the groups in this study but the packed cell volume was significantly decrease in T-5 group compared with both the negative and positive control groups.

Table 3: Hematological Parameters of Clarias gariepinus fed graded levels of Gongronema latifolia based diets

\begin{tabular}{|l|l|l|l|l|l|}
\hline Parameters & T-1 (+tive control) & $\begin{array}{l}\text { T-2 (-tive control } \\
\text { (antibiotics) }\end{array}$ & T-3 (150mg) & T-4 (300mg) & T-5 (500mg) \\
\hline RBC X(10 cells/L) & $2.53 \pm 0.30$ & $2.32 \pm 0.31$ & $1.82 \pm 0.74$ & $2.01 \pm 0.38$ & $1.62 \pm 0.92$ \\
\hline PCV $(\%)$ & $39.23 \pm 4.56$ & $32.27 \pm 2.04$ & $28.10 \pm 9.36$ & $29.50 \pm 4.65$ & $14.25 \pm 8.23^{* a}$ \\
\hline $\mathrm{Hb}(\mathrm{g} / \mathrm{L})$ & $15.10 \pm 1.57$ & $13.0 \pm 1.06$ & $11.43 \pm 3.50$ & $12.17 \pm 1.40$ & $9.70 \pm 5.11$ \\
\hline MCV(FI) & $7.00 \pm 4.36$ & $10.00 \pm 7.00$ & $65.29 \pm 9 . *^{* \mathrm{a}}$ & $61.43 \pm 4.55^{* \mathrm{a}}$ & $61.57 \pm 4.92^{* \mathrm{a}}$ \\
\hline $\mathrm{MCH}(\mathrm{pg})$ & $155.13 \pm 5.88$ & $139.57 \pm 9.61^{*}$ & $158.73 \pm 16.68$ & $148.13 \pm 11.45$ & $151.63 \pm 4.91$ \\
\hline MCHC (g/L) & $59.73 \pm 1.04$ & $56.87 \pm 2.91$ & $41.03 \pm 2.76^{* \mathrm{a}}$ & $41.47 \pm 2.35^{* \mathrm{a}}$ & $40.60 \pm 3.73^{* \mathrm{a}}$ \\
\hline WBC $\left(10^{9}\right.$ cells/L) & $61.13 \pm 5.73$ & $53.83 \pm 6.00$ & $44.90 \pm 7.75^{*}$ & $35.80 \pm 2.88^{* \mathrm{~b}}$ & $27.93 \pm 2.38^{* \mathrm{~b}}$ \\
\hline MONO (\%) & $38.53 \pm 1.65$ & $40.77 \pm 0.66$ & $13.33 \pm 9.07^{* \mathrm{a}}$ & $8.67 \pm 6.03^{* \mathrm{a}}$ & $12.67 \pm 9.29^{* \mathrm{a}}$ \\
\hline LYPH (\%) & $6.27 \pm 0.58$ & $0.20 \pm 0.10^{*}$ & $0.70 \pm 0.36^{* \mathrm{a}}$ & $0.47 \pm 0.15^{* \mathrm{a}}$ & $0.47 \pm 0.38^{* \mathrm{a}}$ \\
\hline NEUT\% & $99.55 \pm 0.89$ & $99.57 \pm 0.15$ & $98.47 \pm 0.68$ & $99.10 \pm 0.46$ & $98.70 \pm 1.56$ \\
\hline RWD\% & $15.17 \pm 0.70$ & $15.97 \pm 0.31$ & $20.53 \pm 9.16$ & $14.86 \pm 0.82$ & $17.33 \pm 2.81$ \\
\hline
\end{tabular}

Means with different superscripts along the row are significantly different $(\mathrm{P}<0.05)$

* Significant different compared with T-1 group, ${ }^{\mathrm{b}}$ Significant different compared with T-2 group PCV - Packed Cell Volume, Hb - Hemoglobin, RBC - Red Blood Cell, WBC - White Blood Cell, LYPH - Lymphocyte, MCV mean corpuscular volume, MCHC - mean corpuscular hemoglobin concentration, MCH -mean corpuscular hemoglobin, MONO - monocyte, RWD- red blood cell distribution width.

Hemoglobin concentration was not also significantly different between all the groups. However, $\mathrm{MCH}$ was significantly reduced in T-2 group compared with the control group result. MCHC was significantly reduced in all extract treated groups compared with both the positive (T-1) and negative (T-2) control. MCV was also significantly decreased in all groups fed with feed supplemented with extract compared with both positive and negative control.

\section{Biochemical Parameters of Clarias gariepinus Juveniles Fed With graded levels of Gongronema latifolia}

Various biochemical parameters of Clarias gariepinus were analyzed after been fed different concentrations of Gongronema latifolia diets and the different results are presented in Table 4. There was no change in the level of AST and GSH across all the treated groups compared to both positive and negative control. Though there was a significant decrease in the level of ALT, globulin and Protein in the treated group relative to the control, but no significant difference noticed among graded levels of Gongronema latifolia treated diets. Albumin level was also significantly increased T2, T-3 and T-5 groups compared with positive control group. The albumin to globulin ratio was significantly increased in all extract supplemented groups and T-2 group compared with positive control results. The level of SOD and MDA were significantly reduced in all groups fed with feed supplemented with extract compared with control. MDA level was however, significantly different among Gongronema latifolia treated groups relative to both the negative and positive controls. CAT level was also significantly reduced among the Gongronema latifolia supplemented feed relative to positive negative control group. 
Table 4: Blood biochemical parameters of Clarias gariepinus fed feed supplemented with graded levels of Gongronema latifolia extract compared with normal diets and diets supplemented with antibiotics.

\begin{tabular}{|l|c|c|c|c|c|}
\hline Parameters & T1(+ve control) & $\begin{array}{c}\text { T2 (-tive control) } \\
\text { (antibiotics) }\end{array}$ & T3(150mg) & T4(300mg) & T5(500mg) \\
\hline AST (u/l) & $65.67 \pm 29.02$ & $63.33 \pm 24.38$ & $76.33 \pm 36.53$ & $79.33 \pm 19.50$ & $88.67 \pm 17.50$ \\
\hline ALT (u/l) & $35.67 \pm 11.47$ & $18.00 \pm 1.53^{*}$ & $19.33 \pm 3.22^{*}$ & $18.67 \pm 4.33^{*}$ & $16.00 \pm 5.20^{*}$ \\
\hline ALP $(\mathrm{u} / \mathrm{l})$ & $12.00 \pm 1.00$ & $16.33 \pm 3.18^{*}$ & $18.33 \pm 4.04^{*}$ & $15.67 \pm 2.51^{*}$ & $15.00 \pm 1.25^{*}$ \\
\hline PROT(g/dl) & $52.67 \pm 4.73$ & $41.67 \pm 1.33^{*}$ & $44.67 \pm 3.06^{*}$ & $44.67 \pm 6.66$ & $41.67 \pm 4.51^{*}$ \\
\hline ALB (g/dl) & $10.67 \pm 0.58$ & $13.33 \pm 1.53^{*}$ & $13.33 \pm 1.53^{*}$ & $12.00 \pm 2.65$ & $13.00 \pm 1.00^{*}$ \\
\hline GLB (g/dl) & $42.00 \pm 4.15$ & $28.34 \pm 0.98^{*}$ & $31.34 \pm 1.53^{*}$ & $32.67 \pm 4.01^{*}$ & $28.67 \pm 3.51^{*}$ \\
\hline ALB/GLB & $0.25 \pm 0.00$ & $0.47 \pm 0.02^{*}$ & $0.43 \pm 0.01^{*}$ & $0.37 \pm 0.01^{* a}$ & $0.45 \pm 0.00^{*}$ \\
\hline GSH (umol/l) & $49.92 \pm 11.02$ & $44.08 \pm 1.31$ & $51.49 \pm 5.14^{\mathrm{a}}$ & $48.71 \pm 5.12$ & $32.17 \pm 8.69$ \\
\hline SOD (mg/min) & $145.47 \pm 3.18$ & $157.81 \pm 5.73^{*}$ & $131.07 \pm 2.13^{* \mathrm{~b}}$ & $130.88 \pm 2.01^{* \mathrm{~b}}$ & $133.61 \pm 4.68^{* \mathrm{~b}}$ \\
\hline CAT(unit/mg protein) & $655.22 \pm 89.48$ & $749.28 \pm 3.26^{*}$ & $524.35 \pm 10.39^{* \mathrm{a}}$ & $560.28 \pm 17.40^{\mathrm{a}}$ & $507.83 \pm 74.64^{\mathrm{a}}$ \\
\hline MDA (nmol/ml) & $1.86 \pm 0.03^{\mathrm{b}}$ & $3.69 \pm 0.15^{*}$ & $1.26 \pm 0.34^{* \mathrm{~b}}$ & $1.21 \pm 0.03^{* \mathrm{a}}$ & $1.13 \pm 0.05^{* \mathrm{a}}$ \\
\hline
\end{tabular}

Means with different superscripts along the row are significantly different $(\mathrm{P}<0.05)$

* Significant different compared with T-1 group, ${ }^{\mathrm{b}}$ Significant different compared with T-2 group, AST-Aspartate aminotransferase, ALT-Alanine aminotransferase, ALP-Alkaline phosphatase, PROT-Plasma Protein, ALB- albumin, GLB- Globulin, GSH- Reduced Glutathione Determination, SOD -Superoxide Dismutase activity, CAT - Catalase activity, MDA- Lipid Peroxidation.

\section{DISCUSSION}

Various extracts from herbs and spices are reported to improve animal growth performance by stimulating the gut secretions or by having a direct bactericidal effect on gut flora with improvement on the protein synthesis leading to improved growth (Citarasu, 2010). Recent development using plant extract with bactericidal potential as a replacement for antibiotics and chemicals in fish cultivation have help to nip in the bud the infectious diseases displayed as a result of intensive cultivation applications in aquaculture industry and possible antibiotic resistance (Mahdavi et al., 2013). The growth recorded in the fishes fed with the herb supplemented diet was due to improved feed utilization Bimrew (2014), opined that efficient feed utilization will engender nutrient assimilation and increased growth. Other author have also reported similar weight gain pattern in similar experimental setup where birds diet is supplemented with Gongronema latifolia extract include Machebe et al (2011). Though there are however reports of no changes to weight in laboratory rats fed the extract of Gongronema latifolia (Iweala and Obidoa 2009). Though previous report has shown that extract of Gongronema latifolia contains high level of crude protein, large reserve of essential amino acid such as leucine, valine and phenylalanine. aspartic acid, glutamic acid and glycine and a lot of saturated and unsaturated fatty acids, antioxidants and antimicrobial activities (Eleyinmi 2007, Iweala and Obidoa 2009; Edim et al., 2012) but in this experiment the herb was used as a supplement so its contribution to the crude protein value of the feed composition, may not be significant.. The differences in growth recorded in the T5 group compared with the positive control group may not be unconnected to the increased concentration of the Gongronema latifolia extract in the feed served to the group which makes it unpalatable for the fish to feed on (Iweala and Obidoa 2009) as a significant reduction was recorded in the total feed intake in the T-5 group (Table 2). Various reports on aquaculture have shown the undeniable contribution of hematology of the culture fishes in terms of the physiochemical property in predicting the health condition and growth efficiency of cultured fish (Harikrishnan et al., 2003). Thus, routine evaluation of the physiochemical characteristics of the fish blood is employed in assessing the fish health status and possible toxicological effects way ahead before 
any manifestation of outward disease or stressful condition (Shah and Altindag 2004). In the present study, there was a significant reduction in the circulating level of the white blood cells in all the extract treated groups due to the significant alteration in the concentration of the monocytes and the lymphocytes. This reduction in circulating white blood cell was also significant when compared with that of the group supplemented with antibiotics. This findings is supported by the work of Akinuga et al (2011) when they fed varing doses of ethanolic extract of Gongronema latifolia to rat . However the non significant reduction in $\mathrm{RBC}, \mathrm{PCV}$ and $\mathrm{Hb}$ were equally as found by Antai et al., (2009)

There was no change to the circulating red blood cell count and hemoglobin concentration in all the groups, this is similar to the findings of Chowtivannakul (2016) when he fed Leucaena leucocephala seed extract to normal rat. The increased MCHC may not be unconnected with the significant increase in the MCV and the possible hemodilution recorded in all extract treated groups. The present findings partly corroborated the report of Bello et al., (2014), where they reported no significant changes in hematology of Clarias gariepinus after supplementing their feeding with $G$. latifolia diets.

Liver stress biomarkers which are also biomarkers of toxicity are useful and routinely used in determining onset of diseases and metabolic disturbances in the fish culture (Dobbs et al., 2003). In this study, liver toxicity assessment revealed a non significant increase in serum AST and ALP levels relative to the control while ALT was significantly reduced in all extract treated groups compared to control. ALT is more specific function and its a better indication of liver damage, it could then be concluded that the significant decrease in the level of ALT in fish fed the $G$. latifolium supplemented diets confirm that the extract has hepato protective functions; invariably no liver damage and as such, no leakages of liver enzymes as shown in the MDA values of fish fed on treated diets relative to the control (Akpan and Ekpo 2015). Generally an increase in these liver enzymes indicates injury or toxicity to the organ (Ghadi, 2000). Similar results of a reduction in serum MDA, ALT, SOD and CAT was reported by Henry and Arit (2015), on their study on the biomarker of oxidative stress and liver damage in diabetic rats fed diets containing Gongronema latifolia leaves extract. This significant reduction in SOD and CAT according to Akpan and Ekpo (2015) and Fawole et al (2015) was attributed to leaf extract capability to scavenge or neutralise free radicals generated due to oxidative stress and an improve in fish defence system. The results of the present study revealed that fish fed on different levels of extract of Gongronema latifolia had significant reduction in serum antioxidant enzymes; SOD and MDA compared to the level in the positive control group while GSH level remain significantly unchanged. This gave an indication of possible antioxidant activities of Gongronema latifolia in the fishes at the different doses employed in this study. The antioxidant activities of Gongronema latifolia has previously been reported in rats (Essien et al, 2007; Atangwho et al, 2009; Iweala and Obidoa 2009). That GSH level was not changed could further buttress the nontoxic nature of the extract of Gongronema latifolia added to the feed of the fishes.

\section{CONCLUSION}

The present study showed that supplementation of juvenile Clarias gariepinus meal with extract of Gongronema latifolia improved their feed consumption, feed utilization, growth and weight gained. It also showed that the extract of Gongronema 
latifolia lowered white blood cell count and some biomarkers of liver toxicity and oxidative stress but no adverse effect red blood cell, pack cell volume and haemoglobin concentration in circulation.

\section{RECOMMENDATIONS}

From the findings of this research, it could be recommended that fish farmers could use Gongronema latifolia in formulating fish diets for Clarias gariepinus as an alternative to antibiotics and other chemicals used in fish feed for better productions. The best recommended dosage based on this study is $220 \mathrm{mg}$.

\section{REFERENCES}

Aderolu, A.Z. and Akpabio, V.M. (2009). Growth and economic performance of Q1222Clariasgariepinus juveniles fed diets containing velvet beans, Mucunapuriens and seed meal. Afric. J. Aqua. Sci., 34(2): 1-5

Aderolu, A.Z.; Lawal, M.O.; Soyinka, O.O.; Adeleke, A.T. and Bello, M.D. (2017).Antimicrobial and antioxidant properties of African medicinal plants. J. Coast Life Med. 5(1):16-21.

Akinnuga, A.M.; Bamidele, O.; Ekechi, P. and Adeniyi, O.S. (2011). Effects of an ethanolic leaf extract of Gongronema latifolium on some Haematological parameters in rats. Afr. J. Biomed. Res., 14: 153-156.

Akpan, H.D. and Ekpo, A.J. (2015). Protective role of diets containing Gongronema latifolium leaves on Streptozotocin- induced oxidative stress and liver damage. J. Appl. Pharm. Sci., 5(3): 85-90.

Aksenes, A. and Njaa, L. (1981). Determination of catalase activity in fish. Comp. Biochem. Physiol., 69: 893-896.

American Society for Testing and Materials (2001).Standard test method for estimating acute oral toxicity in rats. ASTM E116387, Philadephia, USA., P. $55-62$

Antai, A.B.; Ofem, O.E.; Ikpi, D.E.; Ukafia, S. and Agiang, E.A. (2009). Phytochemistry and haematological changes following oral administration of ethanolic root extract of Gongronema latifolium in rats. Nig. J. Physio. Sci., 24: 79-83.

Atangwho, I.J.; Ebong, P.E.; Eyong, E.U.; Williams, I.O.; Eteng, M.U. and Egbung, G.C. (2009). Comparative chemical composition of leaves of some antidiabetic medicinal plants: Azadirachta indica, Vernonia amygdalina and Gongronema latifolium. Afri. J. Biotech., 8(18): 4685-4698.

Bello, M.M.; Samira, M.M.; Massoudi, M.; McClean, P.E.; Cregan, P.B. and Miklas, P.N. (2014). Application of in silico bulked segregant analysis for rapid development of markers linked to Bean common mosaic virus resistance in common bean. BMC Genomics, 15(1): 903.

Bessey, O.A.; Lowry, O.H. and Brock, M.J. (1946).A method for the rapid determination of alkaline phosphatase with fibecubicmillimetres of serum. J. Biol. Chem., 164:321-329.

Bimrew, A. and Yeshambel, M. (2014). Exogenous enzymes in nutrient digestion and health of non-ruminant: Carbohydrases enzyme. Res. J. Agric. Env. Mgt., 3(12): 605-611.

Blaxhall, P.C. and Daisley, K.W. (1973).Routine hematological methods for use with fish blood. J. Fish Biol., 5: 771-781. 
Buege, J.A. and Aust, S.D. (1978).Microsomal lipid peroxidation. Methods Enzymology, 52: 302-310.

Chattopadhyah, R.R. (1999). Comparative evaluation of some blood sugar lowering agents of plant origin. J. Ethnopharmacol. 67: 367-372.

Chowtivannakul, P.; Srichaikul, B. and Talubmook, C. (2016). Antidiabetic and antioxidant activities of seed extract from Leucaena leucocephala (Lam.). de Wit. Agric. Nat. Res., 50(5): 357-361.

Citarasu, T. (2010). Herbal biomedicines: a new opportunity for aquaculture industry. Aqua. Int., 18: 403-414.

Citarasu, T.; Venket, R.K.; Raja, J.S.; Micheal, B.M. and Marian, M. (2003). Influence of the antibacterial herbs, Solanum trilobatum, Andrographis paniculata and Psoraleacorylifolia on the survival, growth and bacterial load of Penaeus monodon post larvae. Aqua. Int.,11: 583-595.

Cos, P.; Vlietinck, A.J.; Berghe, D.V. and Maes, L. (2006). Anti-infective potential of natural products: how to develop a stronger in vitro 'proof-of-concept'. J. ethnopharmacol., 106(3): 290-302.

Dobbs, B.R.; Van Dalen, R.; Bagshaw, P.F. and Robertson, P.F. (2003).The utility of laparoscopy in the diagnosis of acute appendicitis in women of reproductive age. Surgical, (17): 1311-1313.

Donmas, C.T.; Watson, W. and Briggs, H. G. (1971). Albumin standards and the measurement of serum albumin with bromocine-sol green. Clinica Chacto, 31: 87-96.

Duncan, D.B. (1955). Multiple ranges and multiple F-test. Biometrics, 11: 1042.

Edim, E.H.; Egomi, U.G.; Ekpo, U.F. and Archibong, E.U. (2012). A review on Gongronema latifolium (Utasi): A novel antibiotic against Staphylococcus aureus related infections. Int. J. Biochem. Biotech., 1(8): 204-208.

EleyinmiAfolabi, F. (2007) Chemical composition and anti-bacterial activity of Gongronema latifolium. J. Zhejng Univ. Sci., 13: 1572 - 1581.

Emeka, E.J.; Iweala, O. and Obidoa, O. (2009) Effect of long term consumption of a diet supplemented with leaves of Gongronema latifolium benth on some biochemical and histological parameters in male Albino rats. J. Biol. Sci., 9(8): 859-865.

Essien, J.P.; Ebong, G.A. and Akpan, E.J. (2007). Antioxidant and antitussive properties of Gongronema latifolium leaves used locally for the treatment of Fowl cough in Nigeria. J. Appl. Sci. Env. Mgt. 11(4): 47-50.

Fawole, F.J.; Sahu, N.P.; Pal, A.K. and Ravindran, A. (2015). Haematoimmunological response of Labeo rohita (Hamilton) fingerlings fed leaf extracts and challenged by Aeromonas hydrophila. Aqua. Res., 1-12.

Ghadi, P.S. (2000). Disorders of liver. Pathophysiology for pharmacy career publication, Nashik 2nd Edition. P. 106-108, 125-130.

Gornall, A.G.; Bardawill, C.J. and David, M. M. (1949). Determination of serum proteins by means of the biureto reaction. J. Biol. Chem.177: 751-766.

Harikrishnan, R.; Rani, M.N. and Balasundaram, C. (2003). Hematological and biochemical parameters in common carp, Cyprinus carpio, following herbal treatment for Aeromonas hydrophila infection. Aqua., 221(1): 41-50.

Henry, D.A. and Arit, J.E. (2015). Protective role of diets containing Gongronema latifolium leaves on Streptozotocin- induced oxidative stress and liver damage. J. Appl. Pharm. Sci., 5(3): 85-90.

Igbinosa, E.O. and Odjadjare, E.E. (2015). Antibiotics and Antibiotic resistance determinants: an undesired element in the environment. In book: The Battle 
Against Microbial Pathogens: Basic Science, Technological Advances and Educational Programs Edition: Volume 2 Publisher: Formatex Research Center Editors: A. Méndez-Vilas

Machebe, N.S.; Agbo, C.U. and Onuaguluchi, C.C. (2011). Oral administration of Gongronema latifolia leaf meal: implications on carcass and heamatological profile of broilers finishers raised in the humid. Afri. J. Biotech., 10(30): 58005805.

Mahdavi, P.; Akhani, H. and van der Maarel, E. (2013). Species diversity and lifeform patterns in steppe vegetation along a $3000 \mathrm{~m}$ attitudinal gradient in the Alborz Mountains, Iran. Folia Geobotanica, 48:7-22.

Mbagwu, I.G. and Adeniyi, H.A. (1988). The nutritional content of Duckweed (Lemna pauciscostatahelgelm) in the Kainji Lake Area - Nigeria. Aqua. Botany, 29(4): 375-366 .

Mbwambo, Z.H.; Mahunnah, R.L. and Kayombo, E.J. (2007). Traditional health practitioner and the scientist: bridging the gap in contemporary health research in Tanzania. Tanzania J. Health Res., 9(2): 115-120.

Morebise, O.; Fafunso, M. A.; Makinde, J.M. and Olajide, O.A. (2006). Evaluation of the bioactivity of Gongronema latifolium leaf extract in rodents. Sci. Focus, 11(1): 27-30.

Nelson, M.S. (1965). Introduction to flowering plants of West Africa.University of London Press. London. P. 245.

Pavrez, M.; Mahboob, H.K.; Zahuul, I. and Shek, M.H. (2005). Antimicrobial activities of the petroleum ether, methanol and acetone extracts of Kaempferia galangal. srhizome. J. Life Earth Sci., 1: 25-29.

Reitman, S. and Frankel, S. (1957). Glutamic - pyruvate transaminase assay by colorimetric method. Am. J. Clin. Path., 28: 56.

Roberts, R.J (1978). Fish pathology, BailliereTindall, London.

Sedlak, J. and Lindsay, R.H. (1968). Estimation of total protein-bound, and nonprotein sulfhydryl groups in tissue with Ellman's reagent. Analytical Biochem., 25: 1192-1205.

Shah, S.L. and Altindag, A. (2004). Haematological parameters of tench (Tincatinca L.) after acute and chronic exposure to lethal and sublethal mercury treatments.Bull. Environ. Contam.Toxicol.73: 911 - 918.

Sofowora, A.; Ogunbode, E. and Onayede, A. (2013). The role and place of medicinal plants in the strategies for disease prevention. Afri. J. Tradit. Complement altern. Med., 10(5): 210-229.

Sun, M. and Zigma, S. (1978). An improved spectrophotometer assay of superoxide dismutase based on epinephrine antioxidation. Analytic Biochem., 90: 81-89.

von Wintersdorff, C.J.; Penders, J.; van Niekerk, J.M.; Mills, N.D.; Majumder, S.; van Alphen, L.B. and Wolffs, P.F. (2016). Dissemination of antimicrobial resistance in microbial ecosystems through horizontal gene transfer. Frontiers microbial., 7: 173.

Wegener, H.C. (2012). Antibiotic resistance-linking human and animal health. In: Institute of Medicine (US). Improving Food Safety through a One Health Approach: Workshop Summary. Washington (DC): National Academies Press (US). A15. https://www.ncbi.nlm.nih.gov/books/NBK114485/ 